\title{
PENGGUNAAN TZ SEBAGAI ANTI PRAKOAGULASI LATEKS PADA PROSES PEMBUATAN RSS DENGAN PENGGUMPAL ASAM FORMAT
}

The Use of TZ to Prevent Latex Precoagulation in RSS Making Process with Formic Acid Coagulant

\author{
Henry Prastanto \\ Pusat Penelitian Karet \\ J1. Salak No 1 Bogor, 16151 \\ Email : hprastanto@yahoo.com
}

Diterima 26 Oktober 2018 / Direvisi 29 November 2018 / Disetujui 18 Desember 2018

\begin{abstract}
Abstrak
Ribbed Smoked Sheet (RSS) adalah salah satu produk karet mentah berupa lembaran yang diproses dari lateks kebun dengan disertai pengasapan. Amonia biasa digunakan sebagai pengawet lateks agar tidak terjadi prakoagulasi sebelum dibuat RSS. Amonia mempunyai sifat basa sehingga berdampak pada penggunaan bahan penggumpal asam format dalam jumlah yang lebih banyak. Pengurangan jumlah bahan penggumpal perlu diteliti lagi dengan menggunakan pengawet sekunder yang tidak menaikkan $\mathrm{pH}$ yaitu Tetramethyl thiuram disulfide-zinc oxide(TZ). Tujuan dari penelitian ini adalah untuk mengurangi penggunaan amonia dengan penambahan pengawet sekunder TZ. Efektifitas penggunaan pengawet sekunder dievaluasi dari keawetan lateks, konsumsi bahan penggumpal dan karakteristik air limbah yang dihasilkan. Percobaan pengawetan lateks dilakukan pada skala laboratorium dengan konsentrasi amonia $0,05 \%$ dan memvariasikan dosis TZ 0,$01 ; 0,02$; 0,$03 ; 0,04 ; 0,05 \% \mathrm{v} / \mathrm{v}$. Sebagai pembanding lateks diawetkan dengan amonia saja dengan konsentrasi $0,1 \%$. Hasil penelitian menunjukkan, bahwa dosis pengawet ammonia 0,05\% dikombinasikan dengan TZ $0,03 \%$ adalah dosis yang optimum. Pada konsentrasi tersebut, lateks mengalami prakoagulasi setelah 17 jam. Konsumsi penggumpal asam format berkurang $24,41 \%$.
\end{abstract}

Karakteristik limbah cair pengolahan RSS berpengawet $\mathrm{TZ} 0,03 \%+\mathrm{NH}_{3} 0,05 \%$ adalah : BOD turun 7,9\%; COD turun 21,5\%; TSS turun $18 \%$; $\mathrm{pH} 5,2 ; \mathrm{N}$-amonia turun $34,5 \%$; Ntotal turun $12,5 \%$; dan logam Zn naik 120\%.

Kata kunci: tetramethyl thiuram disulfide-zinc oxide(TZ), prakoagulasi lateks, RSS, air limbah karet

\section{Abstract}

Ribbed Smoked Sheet (RSS) is one of the raw rubber products in the form of sheets which are processed from garden latex with smoked. Ammonia is commonly used as a latex preservative to prevent precoagulation before making RSS. Ammonia has alkaline properties so that it has an impact on the use of formic acid coagulant in a greater amount. To reduce the amount of coagulation material, it is necessary to examine the use of secondary preservatives which do not raise $p H$, namely Tetramethyl thiuram disulfide-zinc oxide (TZ). The purpose of this study was to reduce the use of ammonia with the addition of $T Z$ secondary preservatives. The effectiveness of the use of secondary preservatives is evaluated from the durability of latex, consumption of coagulation materials and the characteristics of the waste water produced. Latex preservation experiments were carried out on a laboratory scale with $0.05 \%$ ammonia concentration and varying the $T Z 0.01$ dose; 0.02; 0.03; 0.04; 0.05\% v / v. As a comparison, 
latex is preserved with ammonia only with a concentration of $0.1 \%$. The results showed that the preservative dose of $0.05 \%$ ammonia combined with $0.03 \% \mathrm{TZ}$ was the optimum dose. At this concentration, the latex was pracoagulated after 17 hours. Consumption of formic acid coagulation was reduced by $24.41 \%$. Characteristics in the concentration of TZ-preserved RSS processing wastewater $0.03 \%+0.05 \% \mathrm{NH}_{3}$ are $\mathrm{BOD}$ down 7.9\%; COD down; TSS down 18\%; $p H$ 5,2; $\mathrm{N}$ ammonia down 34.5\%; $N$-total down $12.5 \%$; and Zn metal is up $120 \%$.

Keywords : tetramethyl thiuram disulfide-zinc oxide (TZ), precoagulation latex, RSS, rubberwastewater

\section{Pendahuluan}

Lateks karet alam hasil penyadapan dari perkebunan karet mengandung karet, air, protein, karbohidrat, senyawa organik, abu, resin dan mikroorganisme. Protein dalam lateks berfungsi sebagai lapisan pelindung, dimana protein memberikan muatan negatif yang mengelilingi partikel sehingga mencegah terjadinya penyatuan antar partikel karet (prakoagulasi). Lateks karet alam akan mengalami koagulasi atau penggumpalan secara alami beberapa jam setelah penyadapan. Waktu yang diperlukan lateks untuk menggumpal sangat tergantung dari suhu lingkungan dan kestabilan lateks (Blackley, 1966). Penggumpalan lateks tersebut utamanya disebabkan oleh adanya aktivitas mikroorganisme yang terdapat dalam lateks karet alam. Karbohidrat dan senyawa organik akan diuraikan oleh mikroorganisme dalam lateks sehingga menghasilkan senyawa yang bersifat asam yang dapat menurunkan $\mathrm{pH}$ lateks sehingga dapat merusak kestabilan lateks.

Penggumpalan lateks akan menjadi masalah apabila lokasi kebun karet cukup jauh dari lokasi pengolahan lateks menjadi produk. Penggumpalan lateks sebelum lateks tiba dipabrik pengolahan akan menyebabkan kerugian bagi perkebunan karet karena karet yang dihasilkan akan bermutu rendah atau memiliki harga yang lebih murah. Untuk mencegah penggumpalan ataupun prakoagulasi sebelum lateks diolah, pada umumnya ditambahkan antikoagulan.

Keawetan lateks kebun sangat tergantung dari dosis antikoagulan dalam lateks kebun. Semakin tinggi dosis antikoagulan yang digunakan maka lateks kebun akan semakin awet pula. Namun penambahan antikoagulan yang berlebihan tentu akan menyebabkan pemborosan dan juga akan berdampak pada mutu air limbah yang menjadi kurang baik. Pengawet lateks yang ideal harus dapat membunuh mikroorganisme atau setidaknya dapat menekan aktifitas mikoorganisme, menaikan $\mathrm{pH}$, dan dapat menjadikan logam dalam lateks khususnya ion logam berat menjadi tidak aktif (Triwijoso \& Siswantoro, 1986).

Pengawet lateks yang paling banyak digunakan adalah amonia. Pengawet lain yang dapat digunakan diantaranya adalahTetramethyl thiuram disulfide - zinc oxide (TZ), sodium pentachlorphenate (SPP) dan asam borat. Penggunaan bahan pengawet ini masih menggunakan amonia namun dalam jumlah yang lebih sedikit. Penelitian pengawet lateks lainnya yang dilakukan dalam skala laboratoium juga terus dilakukan. Bahan biologis dari ekstrak jamur dan bakteri telah diteliti untuk digunakan sebagai pengawet selain amonia (Hasan \& Singh, 2014). Penggunaan surfaktan dari mikroba sebagai pengawet lateks juga telah dilakukan (Zuhainis et al., 2015). Pengawet Zinc Sulfat $\left(\mathrm{ZnSO}_{4}\right)$ juga telah digunakan sebagai alternatif pengawet lateks (Chaikumpollert et al., 2000). Chitosan dan turunannya juga telah diteliti sebagai pengawet untuk lateks karet alam (Loykulnant et al., 2012).

Ribbed Smoked Sheet (RSS) adalah salah satu produk berupa lembaran karet mentah yang diproses dari lateks kebun dengan disertai pengasapan. Amonia biasa digunakan sebagai pengawet lateks agar tidak terjadi prakoagulasi sebelum dibuat RSS. Namun penggunaan 
amonia ini seringkali menimbulkan masalah terutama tentang banyaknya konsumsi bahan penggumpal asam format dan buruknya kualitas air limbah yang dihasilkan. Masalah limbah seringkali menjadi problem bagi pabrik karet terlebih semenjak Pabrik Karet RSS diwajibkan memenuhi standar sesuai dengan Keputusan Menteri Perindustrian Republik Indonesia Nomor Nomor 149/MIND/Kep/3/2016 Tentang Penetapan Standar Industri Hijau untuk Industri Pengasapan Karet (Ribbed Smoked Sheet Rubber), (Kementerian Perindustrian, 2016). Masalah utama yang dihadapi oleh industri karet RSS dalam pengelolaan air limbah yaitu tingginya $\mathrm{BOD}, \mathrm{COD}, \mathrm{N}-\mathrm{NH}_{3}$ dan $\mathrm{N}$ total sehingga air limbah harus diatasi dengan benar agar memenuhi Baku Mutu Air Limbah yang ditetapkan oleh Kementerian Lingkungan Hidup (Tabel 1). Asia \& Akporhonor (2007) juga menyatakan tingginya kadar bahan pencemar dari limbah pabrik karet sehingga perlu diproses terlebih dahulu sebelum dibuang ke lingkungan. Emisi gas karbon dioksida keseluruhan dari produksi lateks pekat, STR 20, dan jumlah RSS di Thailand termasuk dari pengolahan limbahnya adalah 0,54; 0,70, dan 0,64 ton $\mathrm{CO}_{2}$-eq / ton produk masing-masing (Jawjit et al., 2010). Dengan tren global baru menuju pembangunan berkelanjutan, industri perlu fokus pada teknologi produksi yang lebih bersih,

Tabel 1. Baku mutu air limbah industri karet

\begin{tabular}{lcccc}
\hline & \multicolumn{2}{c}{ Lateks Pekat } & \multicolumn{2}{c}{ Karet Bentuk Kering } \\
\cline { 2 - 6 } \multicolumn{1}{c}{ Parameter } & $\begin{array}{c}\text { Keban } \\
\text { Kadar paling } \\
\text { tinggi }(\mathrm{mg} / \mathrm{L})\end{array}$ & $\begin{array}{c}\text { pencemaran } \\
\text { paling tinggi } \\
(\mathrm{Kg} / \text { ton })\end{array}$ & $\begin{array}{c}\text { Kadar paling } \\
\text { tinggi }(\mathrm{mg} / \mathrm{L})\end{array}$ & $\begin{array}{c}\text { Beban } \\
\text { pencemaran } \\
\text { paling tinggi } \\
\text { (Kg/ton) }\end{array}$ \\
\hline BOD $_{5}$ & 100 & 4 & 60 & 2,4 \\
COD & 250 & 10 & 200 & 8 \\
TSS & 100 & 4 & 100 & 4 \\
Ammonia Total & 15 & 0,6 & 5 & 0,2 \\
Nitrogen Total & 25 & 1,0 & 10 & 0,4 \\
Logam Zn & 1,0 & 0,02 & 1,0 & 0,02 \\
pH & \multicolumn{2}{c}{$6,0-9,0$} & & $6,0-9,0$ \\
Debit limbah paling tinggi & $40 \mathrm{~m}^{3}$ per ton produk karet & $40 \mathrm{~m}^{3}$ per ton produk karet
\end{tabular}

Sumber: Kementerian Lingkungan Hidup (2014)

minimisasi limbah, pemanfaatan limbah, pemulihan sumber daya dan daur ulang air (Mohammadi etal., 2010).

Salah satu cara yang cukup efektif dalam mengurangi bahan pencemar yang diterapkan oleh pabrik karet adalah dengan mengurangi kadar bahan pencemar sejak dari sumbernya (Yasin, 2018). Sumber bahan pencemar utama bagi pabrik karet RSS adalah amonia dan asam format.

Pengawet Tetramethyl Thiuram DisulfideZink Oxide (TZ) adalah pengawet yang paling banyak diterapkan dalam skala komersial setelah amonia dan tidak ada kesulitan penerapannya. Pengawet tersebut tidak memiliki efek buruk pada sifat-sifat lateks pekat (Rao, 1976). Beberapa perkebunan karet penghasil lateks pekat di Indonesia telah menggunakan TZ sebagai pengawet lateks sebelum diolah menjadi lateks pekat, namun belum ada perkebunan yang menggunakan TZ sebagai pengawet pada proses pembuatan RSS. Penggunaan TZ ini berpotensi mengurangi penggunaan amonia dan bahan penggumpal, 
sehingga akan berdampak positif bagi ekonomi serta mutu air limbah yang dihasilkan. Oleh karena itu perlu dilakukan penelitian untuk menentukan dosis optimum pengawet $\mathrm{TZ}$ terhadap waktu keawetan lateks yang dihasilkan, menentukan dosis penggumpal asam format serta karakteristik limbah cair pengolahan RSS berpengawet TZ. Mutu air limbah diidentifikasi dengan pengujian nilai $\mathrm{BOD}, \mathrm{COD}$, TSS, $\mathrm{pH}$ dan $\mathrm{N}$ Amonia pada limbah cair tersebut, sehingga dampak positif dan negatif dari penggunaan TZ sebagai pengawet lateks untuk pembuatan RSS dapat diketahui tingkat pencemarannya terhadap lingkungan.

\section{Bahan dan Metode}

Lateks kebun diperoleh dari perkebunan karet yang berada di daerah Ciomas-Bogor. Lateks kemudian diawetkan dengan amonia dengan kadar amonia dalam lateks 0,05\%. Lateks kemudian dibagi menjadi 5 sampel (kode B sampai F) untuk selanjutnya kemudian ditambahkan TZ dengan konsentrasi bervariasi tiap sampel, yaitu 0,01 ; 0,$02 ; 0,03 ; 0,04 ; 0,05 \%$ (berat/berat). Sebagai pembanding digunakan lateks dengan pengawet amonia saja dengan konsentrasi $0,1 \% \mathrm{v} / \mathrm{v}$ (sampel A). Lateks kemudian diamati keawetannya yang ditandai dengan adanya prakoagulasi. Metode pengamatan prakoagulasi sama dengan metode pengamatan pada pengujian Mechanical Stability Time (MST) lateks pekat. Waktu yang diperlukan untuk pengangkutan lateks sebelum lateks diolah digunakan sebagai acuan penentuan kadar TZ optimum.

Setelah kadar optimum TZ diketahui maka dibuat sampel lateks dalam jumlah yang lebih besar disertai dengan penambahan pengawet optimumnya. Pada pengolahan RSS, Kadar Karet Kering (KKK) perlu ditentukan nilanya terlebih dahulu sebagai acuan dalam pengenceran lateks kebun. KKK baku yang digunakan untuk pengolahan RSS adalah 15\% sehingga lateks kebun yang memiliki KKK lebih dari $15 \%$ harus diencerkan terlebih dahulu. Lateks kebun yang telah diencerkan kemudian digumpalkan menggunakan asam format hingga lateks memiliki $\mathrm{pH}$ 4,6-4,9 (Suseno, 1989). Konsumsi bahan penggumpal asam format kedua sampel dihitung untuk kemudian dibandingkan.

Lateks yang telah menggumpal dari kedua sampel selanjutnya digiling seperti pada proses pembuatan RSS. Pada proses penggilingan ini karet digiling tanpa pencucian agar serum/limbah cair yang didapatkan adalah serum murni tanpa pengenceran.Untuk mengetahui karakteristik dari limbah cair tersebut, dilakukan analisis dengan beberapa parameter antara lain Biological Oxygen Demand (BOD) (SNI 6989.72:2009), Chemical Oxigen Demand (COD)(SNI 06-6989.2-2009), Total Suspended Solid (TSS)(SNI 06-6989.3-2004), Derajat keasaman (pH)(SNI 06-6989.112004), N-Amonia (SNI 06-6989.30-2005), N total (SNI 19-7020-2004) dan Logam Zink (Zn)(SNI 19-7030-2004).

\section{Hasil dan Pembahasan}

\section{Dosis Optimal Pengawet TZ}

Lateks kebun tanpa pengawet apapun dapat menggumpal secara alami sekitar 5 jam setelah lateks dipanen pada siang hari. Dalam kondisi cuaca kurang baik misalnya setelah hujan lateks dapat menggumpal lebih cepat bahkan tidak sampai 2 jam setelah pemanenan. Beberapa Perkebunan yang memiliki lokasi yang jauh dari Pabrik RSS menggunakan amonia dengan kadar amonia dalam lateks $0,1 \%$ agar lateks menjadi awet. Lateks kebun berpengawet amonia dengan kadar 0,1\% menurut hasil penelitian ini dapat mengawetkan lateks kebun selama 21,5 jam. Berdasarkan kondisi lapangan lokasi perkebunan terhadap pabrik RSS sangat bervariasi jaraknya. Tidak jarang lokasi lokasi Pabrik RSS cukup jauh sehingga perjalanan harus ditempuh dalam waktu 5-10 jam. Selain faktor lokasi, kondisi teknis di Pabrik RSS 
seringkali juga menyebabkan lateks tidak bisa segera diolah menjadi RSS misalnya perlu waktu untuk pengujian KKK dan kendala alatalat. Kondisi ini juga harus diantisipasi sehingga penambahan pengawet amonia $0,1 \%$ ini sudah dianggap aman untuk mencegah prakoagulasi sebelum lateks diolah menjadi RSS.

Dosis amonia sangat berpengaruh pada keawetan lateks. Apabila kadar amonia diturunkan setengahnya dan digantikan dengan TZ tentu akan memberikan tingkat keawetan lateks yang berbeda pula. Data keawetan lateks yang diawetkan dengan 0,05\% amonia dikombinasikan dengan berbagai kadar pengawet TZ disajikan dalam Tabel 2 berikutini.

Berdasarkan Tabel 2 diketahui bahwa kenaikan kadar TZ dapat meningkatkan keawetan lateks, namun dengan penambahan TZ yang terlalu banyak tentu akan menyebabkan pemborosan. Oleh karena itu perlu ditetapkan kadar optimum TZ sehingga sudah cukup aman. Menurut Comes (2007) pengawetan lateks dengan amonia tanpa TZ dalam pembuatan lateks pekat, nilai volatile fatty acid (VFA) dapat meningkat cepat mengindikasikan tingginya aktivitas mikroorganisme. Berdasarkan perkiraan waktu yang diperlukan untuk pengiriman dan persiapan sebelum pengolahan maka waktu 10-15 jam adalah waktu yang sudah cukup memadai. Oleh karena itu dapat ditentukan dosis pengawet TZ yang optimum yang digunakan adalah $0,03 \%$ karena pada konsentrasi tersebut lateks tidak mengalami prakoagulasi hingga 17 jam semenjak pemanenan

\section{pH Lateks Kebun}

Kadar Karet Kering (KKK) lateks kebun dalam penelitian ini diketahui sebesar $44,3 \%$. Lateks kebun sebelum digumpalkan dengan bahan penggumpal harus diencerkan terlebih dahulu sehingga KKK lateks menjadi $15 \%$. Penurunan dosis amonia dan digantikan dengan penambahan TZ memberikan pengaruh pada penurunan $\mathrm{pH}$ lateks. $\mathrm{pH}$ lateks kebun yang sudah diencerkan menjadi $15 \%$ disajikan alam Tabel 3 berikut.

Tabel 2. Keawetan lateks kebun pada berbagai dosis TZ

\begin{tabular}{|c|c|c|c|c|c|}
\hline \multirow[b]{2}{*}{ Kode } & \multirow{2}{*}{$\begin{array}{c}\text { Dosis TZ } \\
(\%)\end{array}$} & \multirow{2}{*}{$\begin{array}{c}\text { Dosis } \\
\mathrm{NH}_{3} \\
(\%)\end{array}$} & \multicolumn{2}{|c|}{ Waktu keawetan } & \multirow[b]{2}{*}{$\begin{array}{c}\text { Rata-rata } \\
\text { (jam) }\end{array}$} \\
\hline & & & $\underset{\text { (jam) }}{\text { Pengamatan } 1}$ & $\begin{array}{l}\text { Pengamatan } 2 \\
\text { (jam) }\end{array}$ & \\
\hline A & 0 & 0,1 & 22 & 21 & 21,5 \\
\hline B & 0,01 & 0,05 & 9 & 11 & 10,0 \\
\hline C & 0,02 & 0,05 & 9 & 12 & 10,5 \\
\hline D & 0,03 & 0,05 & 19 & 15 & 17,0 \\
\hline $\mathrm{E}$ & 0,04 & 0,05 & 19 & 20 & 19,5 \\
\hline $\mathrm{F}$ & 0,05 & 0,05 & 23 & 21 & 22,0 \\
\hline
\end{tabular}

Tabel. $3 \mathrm{pH}$ lateks yang diawetkan tanpa TZ dan dengan TZ sebelum digumpalkan

\begin{tabular}{cccccc}
\hline \multirow{2}{*}{ Kode sampel } & \multirow{2}{*}{$\begin{array}{c}\text { Dosis TZ } \\
(\%)\end{array}$} & $\begin{array}{c}\text { Dosis } \\
\text { amonia (\%) }\end{array}$ & \multicolumn{3}{c}{$\mathrm{pH}$ lateks setelah diencerkan } \\
\cline { 4 - 6 } & $(\%$ menjadi 15\% & \\
\hline A & 0 & 0,1 & 9,02 & 9,00 & 9,01 \\
D & 0,03 & 0,05 & 8,06 & 8,03 & 8,05 \\
\hline
\end{tabular}


Berdasarkan hasil penelitian terlihat bahwa pengurangan dosis amonia dan digantikan dengan $\mathrm{TZ} \mathrm{pH}$ lateks turun dari 9 menjadi 8. $\mathrm{Hal}$ ini karena amonia bersifat basa sedangkan TZ tidak bersifat basa. Dengan demikian penurunan dosis amonia tentu akan berdampak positif karena akan menyebabkan penurunan konsumsi bahan penggumpal asam format.

\section{Hasil Pengukuran Volume Koagulan Asam Format}

Asam format pada proses pembuatan RSS berfungsi penggumpal lateks sebelum proses penggilingan. Pengukuran volume koagulan asam format dilakukan dengan metode titrasi dengan asam format sebagai penitarnya. Titrasi dilakukan hingga $\mathrm{pH}$ menunjukkan pada 4,7 dimana pada $\mathrm{pH}$ tersebut adalah titik isoelektrik pada lateks (Sanguansap et al., 2005). Pada $\mathrm{pH}$ tersebut protein yang terkandung dalam lateks memiliki jumlah muatan negatif yang sama dengan jumlah muatan positifnya, sehingga lateks lateks yang berbeda muatan akan saling menyatu sehingga terjadilah penggumpalan. Volume asam format yang dibutuhkan untuk menggumpalkan $100 \mathrm{~mL}$ lateks pada penelitian ini disajikan dalam Tabel 4 sebagai berikut:
Lateks setelah ditambahkan asam format perlahan-lahan mulai terjadi koagulasi dan dibutuhkankan waktu sekitar 4-6 jam sampai lateks menggumpal sempurna. Lateks dengan pengawet amonia saja menghasilkan $\mathrm{pH}$ yang lebih basa dibandingkan dengan pengawet sekunder TZ, sehingga membutuhkan asam format yang berlebih untuk menurunkan $\mathrm{pH}$ hingga titik isoelektriknya yaitu 4,7. Pada Tabel 3 terlihat bahwa sampel $\mathrm{D}$ hanya membutuhkan 16,1 $\mathrm{mL}$ asam format, sedangkan sampel A membutuhkan volume asam format sebanyak 21,3 $\mathrm{mL}$. Dengan demikian, penambahan pengawet $\mathrm{TZ}$ pada sampel $\mathrm{D}$ dapat menurunkan penggunaan asam format sekitar $24,41 \%$. Penurunan ini sangat berarti karena akan berakibat pada turunnya biaya produksi RSS.

\section{Hasil Analisis Air Limbah}

Proses penggilingan gumpalan karet menjadi lembaran dalam pengolahan RSS akan menghasilkan limbah cair. Limbah tersebut dihasilkan dari sisa-sisa pada proses penggumpalan yang didalamnya mengandung serum yang berasal dari lateks maupun penambahan larutan pengawet dan penggumpal pada saat pengolahan RSS. Hasil uji pada limbah cair pengolahan RSS ini disajikan dalam Tabel 5 berikut ini:

Tabel 4. Volume asam format yang dibutuhkan koagulasi lateks yang diawetkan dengan tanpa TZ (A) dan dengan TZ (D)

\begin{tabular}{|c|c|c|c|c|c|}
\hline \multirow{2}{*}{$\begin{array}{l}\text { Kode } \\
\text { Sampel }\end{array}$} & \multirow{2}{*}{$\begin{array}{c}\text { Dosis TZ } \\
(\%)\end{array}$} & \multirow{2}{*}{$\begin{array}{c}\text { Dosis } \\
\text { Amonia } \\
(\%)\end{array}$} & \multicolumn{2}{|c|}{ Volume asam (mL) } & \multirow{2}{*}{$\begin{array}{c}\text { Rata -rata } \\
\text { Volume (mL) }\end{array}$} \\
\hline & & & $\begin{array}{c}\text { Percobaan } \\
1\end{array}$ & Percobaan 2 & \\
\hline $\mathrm{A}$ & 0 & 0,1 & 22 & 20,6 & 21,3 \\
\hline $\mathrm{D}$ & 0,03 & 0,05 & 16,3 & 15,8 & 16,1 \\
\hline
\end{tabular}


Tabel 5. Karakteristik limbah cair pengolahan RSS dari lateks yang diawetkan menggunakan TZ dan tanpa TZ

\begin{tabular}{cccc}
\hline \multirow{2}{*}{ Parameteruji } & $\mathrm{A}$ & $\mathrm{D}$ & \multirow{2}{*}{ Perubahan (\%) } \\
\cline { 2 - 3 } & $973 \mathrm{ppm}$ & $896 \mathrm{ppm}$ & $-7,9$ \\
\hline BOD & $1472 \mathrm{ppm}$ & $1155 \mathrm{ppm}$ & $-21,5$ \\
COD & $0,16 \mathrm{ppm}$ & $0,13 \mathrm{ppm}$ & -18 \\
$\mathrm{TSS}$ & 4,92 & 5,20 & $+5,3$ \\
$\mathrm{pH}$ & $37,04 \mathrm{ppm}$ & $24,24 \mathrm{ppm}$ & $-34,5$ \\
$\mathrm{~N}_{\mathrm{NH}}$ & $68,29 \mathrm{ppm}$ & $59,75 \mathrm{ppm}$ & $-12,5$ \\
N-Total & $0,05 \mathrm{ppm}$ & $0,11 \mathrm{ppm}$ & +120 \\
Logam $\mathrm{Zn}$ & & & \\
\hline
\end{tabular}

Data yang diperoleh dari analisis air limbah pengolahan RSS menghasilkan perubahan konsentrasi pada tiap parameter uji antara sampel A dengan sampel D. Perubahan konsentrasi pada tiap parameter uji sebagian besar mengalami penurunan konsentrasi seperti pada konsentrasi BOD, COD, TSS, N$\mathrm{NH}_{3}$, dan N-Total. Nilai BOD, COD N-NH dan N-Total sangat dipengaruhi oleh penambahan bahan kimia organik dan anorganik ke dalam lateks. Tingginya dosis amonia dan tingginya kebutuhan asam format jelas akan berdampak pada kenaikan BOD, $\mathrm{COD}, \mathrm{N}-\mathrm{NH}_{3}$ dan N-Total.

Asam format adalah bahan organik yang tentunya akan turut berkontribusi pada kenaikan BOD dan COD dari serum yang dihasilkan dalam proses pembuatan RSS. Bakteri akan menguraikan asam format pada proses pengolahan limbah. Jenis bakteri yang mampu mengurai senyawa asam format adalah bakteri Desulfomaculum rumini (Komala et al., 2012). Pada sampel A konsumsi bahan penggumpal asam format lebih banyak dibandingkan dengan sampel $\mathrm{D}$. Oleh karena itu BOD dan COD pada serum sampel A hasilnya lebih tinggi bila dibandingkan dengan BOD dan COD serum sampel D. BOD pada serum sampel A 7,9\% lebih tinggi dibandingkan serum sampel $\mathrm{D}$ dan COD serum sampel A juga lebih tinggi 21,5\% bila dibandingkan dengan serum sampel A. dengan demikian kombinasi pengawet amonia dan TZ cukup efektif menurunkan BOD dan COD air limbah yang dihasilkan.
Pemakaian amonia dalam proses pengawetan lateks sebelum pengolahan RSS akan mempengaruhi kualitas air limbah yang dihasilkan. Pada penelitian ini kadar $\mathrm{N}-\mathrm{NH}_{3}$ pada air limbah pengolahan RSS sampel D adalah 24,24 ppm. Sedangkan kadar $\mathrm{N}^{-\mathrm{NH}_{3}}$ pada air limbah pengolahan RSS sampel A adalah 37,04 ppm. Pengurangan dosis amonia disertai dengan penggunaan $\mathrm{TZ}$ terbukti menurunkan kadar $\mathrm{N}^{-\mathrm{NH}_{3}}$ sehingga dapat menurunkan beban pada unit pengolahan limbah berikutnya. Penurunan kadar $\mathrm{N}^{-\mathrm{NH}_{3}}$ dari sampel A dan sampel D adalah sebesar $34,5 \%$. Dengan demikian, penggunaan pengawet TZ 0,03\% pada pengolahan RSS akan berpengaruh baik pada air limbahnya. Karena kadar $\mathrm{N}_{-} \mathrm{NH}_{3}$ pada air limbah yang dihasikan lebih sedikit dibanding tanpa pengawet TZ. Selain nitrogen dalam bentuk amonia, nitrogen dalam limbah organik dapat berupa nitrogen organik, nitrogen anorganik lain, nitrogen nitrat, dan dapat berupa nitrogen nitrit. Nitrogen total merupakan jumlah dari nitrogen organik, anorganik, nitrat, dan nitrit yang terkandung dalam air limbah. Berdasarkan Tabel 4. nilai nitrogen total pada pengolahan RSS berpengawet amonia saja yaitu sebesar 68,29 ppm, sedangkan nilai nitrogen total pada pengolahan RSS berpengawet sekunder TZ yaitu sebesar 59,75 ppm atau turun sebesar $12,5 \%$.

$\mathrm{pH}$ serum secara teoritis seharusnya tidak berbeda karena penggumpalan lateks dilakukan pada $\mathrm{pH}$ yang sama. Hasil percobaan menunjukkan perbedaan $\mathrm{pH}$ hanya 
terjadi kenaikan $5,3 \%$ saja yaitu dari 4,92 menjadi 5,20. Hal ini karena adanya sisa TZ dalam serum dapat masih cukup efektif menekan aktifitas mikroorganisme sehingga protein terlarut dalam serum tidak banyak terurai menjadi asam.

Kandungan logam $\mathrm{Zn}$ adalah satu parameter uji yang juga cukup penting untuk diketahui. Analisis logam Zn pada penelitian ini didasari pada penggunaan logam $\mathrm{Zn}$ pada pembuatan pengawet TZ. Logam $\mathrm{Zn}$ ini dihasilkan dari senyawa $\mathrm{ZnO}$ Pada Tabel 5 dapat dilihat bahwa penambahan pengawet TZ mengakibatkan kadar logam Zn pada air limbah meningkat. Kadar logam Zn pada serum sampel $\mathrm{D}$ adalah $0,11 \mathrm{ppm}$ atau naik $120 \%$ bila dibandingkan dengan sampel $\mathrm{A}$. meskipun naik cukup besar namun kadar $\mathrm{Zn}$ tersebut masih jauh dibawah ambang batas mutu air limbah pabrik karet yang ditetapkan oleh pemerintah yaitu $1 \mathrm{mg} / \mathrm{L}$ (ppm).

Total Suspended Solid (TSS) atau padatan tersuspensi total adalah residu dari padatan total yang tertahan oleh saringan dengan ukuran partikel $2 \mu \mathrm{m}$ (SNI 06-6989.3-2004). Kadar TSS yang diperoleh dari air limbah pengolahan RSS ini adalah kadar padatan yang tertahan oleh kertas saring pada saat pemanasan suhu $105^{\circ} \mathrm{C}$. Padatan yang terdapat dalam air limbah dipengaruhi oleh proses penggumpalan pada saat pengolahan RSS. Apabila proses penggumpalan terjadi secara merata dan sempurna, maka padatan yang dihasilkan akan lebih sedikit. Nilai TSS pada air limbah pengolahan RSS sampel D adalah 0,13 ppm. Sedangkan nilai TSS air limbah pengolahan RSS sampel A adalah 0,16 ppm. Dengan adanya penurunan TSS ini menandakan bahwa sampel D dapat menggumpal lebih baik daripada sampel A. tingginya kadar amonia dalam lateks seringkali menyebabkan lateks tidak dapat menggumpal dengan sempurna.

Jika dibandingkan dengan baku mutu air limbah pabrik karet padat maka terlihat bahwa serum atau air limbah yang dihasilkan dalam penelitian ini belum memenuhi syarat untuk dibuang ke lingkungan secara langsung tanpa pengolahan terlebih dahulu. Hal ini dikarenakan air limbah tersebut belum dicampurkan dengan air pencucian selama proses produksi yang jumlahnya cukup banyak. Air limbah hasil penelitian ini juga belum mengalami proses pengolahan air limbah di Instalasi Pegolahan Air Limbah (IPAL). Sistem pengolahan air limbah yang sudah dilakukan di pabrik karet RSS bersifat biologis konvensional seperti lumpur aktif, aerasi, kolom oksidasi, dan wetland belum sepenuhnya mampu memenuhi standar kualitas limbah yang ditetapkan untuk parameter COD, BOD, TSS, dan Nitrogen (NTotal dan Amonia) (Sarengat et al., 2015). Dengan adanya penurunan bahan pencemar air limbah sejak dari sumbernya maka tentu beban pengolahan air limbah di unit pengolahan limbah akan menjadi lebih ringan dan mutu air limbah yang dihasilkan akan menjadi lebih baik.

Secara ekonomi penggunaan pengawet $\mathrm{TZ}$ ini menguntungkan karena harga pengawet TZ dan larutan amonia relatif sama. Penurunan dosis amonia sebesar $0,05 \%$ dan diganti dengan dispersi $\mathrm{TZ} \quad 0,03 \%$ akan dapat menghemat $20 \%$ biaya bahan pengawet. Penurunan dosis bahan menggumpal asam semut juga dapat menghemat biaya bahan penggumpal sebesar $24,41 \%$.

\section{Kesimpulan}

Dosis pengawet lateks kebun optimum untuk pengolahan RSS ialah adalah kombinasi amonia $0,05 \%$ dan TZ $0,03 \%$ yang mampu menahan lateks kebun tanpa prakoagulasi selama 17 jam. Penurunan konsumsi bahan penggumpal pada lateks lateks berpengawet amonia $0,05 \%$ dan TZ $0,03 \%$ bila dibandingkan dengan lateks berpengawet amonia $0,1 \%$ adalah sebesar $24,41 \%$. Kombinasi pengawetan lateks dengan amonia dengan kadar 0,05\% dan TZ 0,03\% efektif digunakan pada proses pembuatan RSS karena mengurangi konsumsi bahan penggumpal 
sekaligus memperbaiki mutu air limbah yang dihasilkan. Secara ekonomi penggunaan pengawet TZ dapat menghemat biaya bahan pengawet sebesar $20 \%$ dan menghemat biaya bahan penggumpal 24,41\% (apakah dari segi ekonomi lebih efisien? Sebaiknya diulas untuk memberikan gambaran apakah dapat dilakukan di pabrik).

\section{Daftar Pustaka}

Asia, I. O., \& Akporhonor, E. E. (2007). Characterization and physicochemical treatment of wastewaterfrom rubber processing factory. International Journal of Physical Sciences, 2(3), 61-67.

Blackley., D. C. (1966). High polymer latices, their science and technology (Vol. 1). London, UK: MacLaren \& Sons LTD.

Chaikumpollert, O., Loykulnant, S., Chaveewan, K., \& Suchiva, K. (2000). Development of preservative for natural rubber latex. Tulisan disajikan pada International Conference of Materials Science and Techonology, Bangkok.

Comes, B. (2007). The Effect Of Particle Size Of $\mathrm{ZnO}$ Preservation For Nnatural Rubber Latex (Doctoral Thesis), University Of Sri Jayewardenepura, Nugegoda.

Hasan, A. A., \& Singh, M. (2014). Biological extracts for preservation of natural rubber latex. MRB Rubber Technology Developments, 14(1), 13-15.

Jawjit, W., Kroeze, C., \& Rattanapan, S. (2010). Greenhouse gas emissions from rubber industry in Thailand. Journal of Cleaner Production, 18(5), 403-411.

Kementerian Lingkungan Hidup. (2014). Baku mutu air limbah industri karet. Jakarta, Indonesia: Kementerian Lingkungan Hidup.

Kementerian Perindustrian. (2016). Keputusan meneteri perindustrian republik indonesia nomor $149 / \mathrm{m}$-ind/kep/3/2016 tentang penetapan standar industri hijau untuk industri pengasapan karet (ribbed smoked sheet rubber). Jakarta, Indonesia: Kementerian Perindustrian.
Komala, P. S., Helard, D., \& Delimas, D. (2012). Identifikasi mikroba anaerob dominan pada pengolahan limbah cair pabrik karet dengan sistem multi soil layering (msl). Jurnal Teknik Lingkungan, 9(1), 913-921.

Loykulnant, S., Kongkaew, C., Chaikumpollert, O., Sanguanthammarong, P., Na Ubol, P., \& Suchiva, K. (2012). Study of chitosan and its derivatives as preservatives for field natural rubber latex. Journal of applied polymer science, 123(2), 913921.

Mohammadi, M., Man, H. C., Hassan, M. A., \& Yee, P. L. (2010). Treatment of wastewater from rubber industry in Malaysia. African Journal of Biotechnology, 9(38), 6233-6243.

Rao, P. S. R., John, C. K., Ng, C. S., Smith, M. G., \& Robert, C. F. (1976). Commercial exploitation of tmtd/zinc oxide preservative system. Tulisan disajikan pada the Rubber Research Institute of Malaysia Planters' Conference, Kuala Lumpur.

Sanguansap, K., Suteewong, T., Saendee, P., Buranabunya, U., \& Tangboriboonrat, P. (2005). Composite natural rubber based latex particles: a novel approach. Polymer, 46(4), 1373-1378.

Sarengat, N., Setyorini, I., \& Prayitno, P. (2015, 28 Oktober). Pengaruh penggunaan adsorben terhadap kandungan amonia (nh3-n) pada limbah cair industri karet rss. Tulisan disajikan pada Seminar Nasional Kulit, Karet dan Plastik ke-4, Yogyakarta.

Suseno, S. (1989). Pedoman teknis pengolahan karet sit yang diasap (ribbed smoked sheet). Bogor, Indonesia: Balai Penelitian Perkebunan.

Triwijoso, S. U., \& Siswantoro, O. (1989). Pedoman teknis pengawetan dan pemekatan lateks hevea. Bogor, Indonesia: Balai Penelitian Perkebunan. 
Yasin, A. (2018). Manajemen limbah pabrik karet dalam rangka penurunan kadar bod (biological oxygen demand). Jurnal Green Growth dan Manajemen Lingkungan, 7(1), 2234.
Zuhainis, S. W., Hassan, A. A., Singh, M., \& Mohamad, R. (2015). Microbial Surfactant for Preservation of Natural Rubber Latex. In M. T. Liong (Ed.), Beneficial Microorganisms in Agriculture, Aquaculture and Other Areas. Cham: Springer International Publishing. 